\title{
Analisis Website Sistem Informasi Akademik (SIA) UNISKA MAB dengan Menggunakan Metode Usability Heuristic Evaluation
}

\author{
Abdurrahman Sidik, S.Sn, M.Ds \\ Fakultas Teknologi Informasi, Universitas Islam Kalimantan Muhammad Arsyad Al-Banjari \\ abdurrahmansidik30@uniska-bjm.ac.id \\ Rina Alfah, M.Kom \\ Fakultas Teknologi Informasi, Universitas Islam Kalimantan Muhammad Arsyad Al-Banjari \\ rina.alfah.05@gmail.com
}

\begin{abstract}
ABSTRAK
Penerapan IT mempermudah terjadinya transformasi dan peningkatan produktifitas di Perguruan Tinggi, salah satunya adalah Sistem Informasi Akademik (SIA). SIA memberikan kemudahan dalam mengelola informasi dan kegiatan administrasi akademik secara online. Faktor yang diperhatikan tidak hanya meningkatkan mutu informasi, namun juga harus memperhatikan estetika serta usability SIA. Peningkatan mutu SIA dapat diperoleh dari feedback oleh pengguna sistem (mahasiswa). Metode untuk mengukur kemudahan dalam mengakses sebuah website yaitu Usability Heuristic Evaluation (UHE). Penelitian ini yaitu penelitian kuantitatif dengan metode survei dan melibatkan 414 mahasiswa yang berasal dari 7 Fakultas di Universitas Islam Kalimantan Muhammad Arsyad Al Banjari dengan menggunakan instrumen kuesioner, observasi, dan wawancara. Hasil penelitian ini menunjukkan bahwa secara keseluruhan mahasiswa merasa puas dengan fungsi SIA, namun tidak puas dari segi tampilan. Tampilan menjadi salah satu hal yang penting agar memudahkan pengguna dalam mencari informasi yang disajikan pada SIA.
\end{abstract}

Kata Kunci: Kepuasan Pengguna, Sistem Informasi Akademik, Tampilan Antar Muka, Usability, Website

\section{PENDAHULUAN}

Perkembangan Information of Technology (IT) mengalami kemajuan yang begitu pesat dalam satu dekade terakhir ini. Berkat adanya IT, setiap orang dapat mengakses berbagai macam data serta informasi. Definisi kata informasi sendiri di artikan sebagai hasil dari pengolahan data yang secara prinsip memiliki nilai atau value yang lebih dibandingkan dengan data mentah [1]. Dengan kata lain informasi tidak bisa diperoleh secara instan, melainkan diolah sedemikian rupa agar informasi tersebut bisa diakses dengan mudah dan cepat. Dalam konteks ini, informasi menjadi kata kunci untuk mendukung dan meningkatkan sebuah organisasi.

Pemanfaatan IT juga merambah ke dunia pendidikan, khususnya Perguruan Tinggi. IT memberikan peluang terjadinya transformasi dan peningkatan produktifitas Perguruan
Tinggi. Salah satunya produk dari pengelolaan informasi adalah Sistem Informasi Akademik (SIA) berbasis website. SIA memberikan kemudahan kepada mahasiswa dalam kegiatan administrasi akademik Perguruan Tinggi secara online. Adapun contoh tata kelola SIA pada Perguruan Tinggi yaitu seperti proses pengisian KRS mahasiswa, informasi KRS dan KHS, transkrip akademik, informasi jadwal kuliah dan ujian, informasi absensi kuliah, rekap pembayaran SPP, detil biaya semester berjalan, informasi kalender kegiatan akademik, serta menu user (login, ubah password, update profil), dll. Salah satu Perguruan Tinggi yang menerapkan SIA adalah Universitas Islam Kalimantan Muhammad Arsyad Al Banjari.

Penerapan SIA pada Perguruan Tinggi biasanya membutuhkan biaya yang cukup besar dengan resiko kegagalan yang tidak kecil. Faktor yang diperhatikan tak hanya difokuskan 
pada pengelolaan informasi, namun juga harus fokus untuk menjaga dan meningkatkan mutu informasi itu sendiri. Terdapat dua sudut pandang utama untuk menentukan baik buruknya sebuah website (dalam penelitian ini adalah SIA). Menurut Beaird, website harus memperhatikan dua aspek, yaitu estetika dan usability. Estetika berfokus pada semua nilai seni dan daya tarik visual pada website, salah satunya adalah tampilan antar muka (interface). Sedangkan usability adalah kemudahan pengguna untuk mencari informasi yang disajikan pada sebuah website [2].

Sebuah website bisa dikatakan baik apabila pengguna dapat mengoperasikannya dengan mudah dan cepat. Tidak sedikit pengguna yang tidak dapat menerima website yang buruk dan mau meluangkan waktu untuk mempelajari suatu website. Atau dengan kata lain, pengguna sangat ingin segera mengerti dengan seketika, atas apa yang disajikan dalam suatu website [3]. Peningkatan mutu SIA dapat diperoleh dari feedback oleh pengguna sistem itu sendiri.

Salah satu metode untuk mengukur kemudahan dalam mengakses sebuah website yaitu Usability Heuristic Evaluation (UHE). UHE adalah evaluasi yang digunakan untuk website atau software berbasis pengguna. Evaluasi ini melibatkan beberapa orang responden guna memberikan masukan yang selanjutnya akan dikategorikan dalam prinsipprinsip heuristik [4]. Interface dan usability dapat menjadi tolak ukur keberhasilan SIA sebuah Perguruan Tinggi. Dengan menggunakan metode UHE, penelitian ini diharapkan dapat mengevaluasi SIA dan memberikan masukan untuk pengembangan website SIA kedepannya.

\section{TINJAUAN PUSTAKA}

\subsection{Sistem Informasi Akademik}

Menurut Sutabri, sistem adalah suatu kumpulan atau himpunan dari unsur, komponen, atau variabel yang terorganisir, saling berinteraksi, saling tergantung satu sama lain, dan terpadu [5]. Dengan kata lain, sistem yaitu kumpulan data dan informasi yang mempunya arti dan nilai nyata bagi penggunanya. Sistem informasi dikembangkan sesuai dengan kebutuhan pengguna. Artinya ada banyak jenis sistem informasi dengan tujuan yang berbeda-beda pula. Perkembangan sistem informasi pada bidang pendidikan memungkinkan pengguna untuk melakukan aktivitas akademik secara online, atau yang disebut dengan Sistem Informasi Akademik (SIA).

Perkembangan dalam penggunaan SIA ini umumnya berbasis website yang dapat diakses melalui jaringan internet. SIA memiliki fungsi yang luas seperti biro administrasi akademik, manajemen data referensi, manajemen data akademik, manajemen pelaporan, manajemen dokumen cetak, manajemen konversi/import data, dan manajemen user/pengguna.

Pada penelitian ini peneliti hanya memfokuskan pada data yang diambil pada bagian manajemen data akademik yang meliputi menu-menu seperti pengisian KRS mahasiswa, informasi KRS dan KHS, transkrip akademik, informasi jadwal kuliah dan ujian, informasi absensi kuliah, rekap pembayaran SPP, detil biaya semester berjalan, informasi kalender kegiatan akademik, serta menu user (login, ubah password, update profil) yang beralamat website yaitu https://sia.uniskabjm.ac.id

\subsection{Usability}

Studi tentang usability sangat penting untuk menentukan kesuksesan sebuah website. Menurut Nielsen, secara umum usability adalah suatu perangkat untuk menilai kualitas dan kemudahan sebuah tampilan pada website [6]. Kata usability juga mengacu pada metode untuk meningkatkan kemudahan dalam penggunaan selama pengguna mengaskes website. Sebuah website memiliki tingkat usability yang tinggi apabila pengguna bisa menemukan atau memperoleh apa yang mereka butuhkan dari website tersebut.

Pada website, usability adalah satu hal penting yang membuat website tersebut bertahan hidup. Jika website sulit digunakan, sulit dibaca, atau tidak menjawab pertanyaan yang dicari pengguna, maka pengguna akan 
meninggalkan website tersebut. Tidak ada satu pun pengguna yang membaca panduan website atau menghabiskan banyak waktu untuk mencari tahu fungsi dan perintah-perintah pada website [7]. Ada banyak website serupa yang tersedia di internet, meninggalkan website adalah pilihan pertama yang akan dilakukan, ketika pengguna menghadapi kesulitan pada website. Apabila website tersebut website $e$ commerce, maka apabila pengguna tidak dapat menemukan produk, maka pengguna akan beralih ke website e-commerce lainnya.

Jika dikaitkan dengan penggunaan SIA, menu-menu serta perintah yang banyak akan berpengaruh dengan tingkat kualitas usability pada SIA. Nielsen kemudian merumuskan salah satu metode untuk mengukur usability sebuah website yaitu Usability Heuristic Evaluation (UHE). Adapun kriteria usability pada UHE yang harus dipenuhi website yaitu: (1) visibilitas status website, (2) keserasian antara website dengan keadaan terkini, (3) kebebasan pengguna untuk mengontrol website, (4) konsistensi dan standarisasi, (5) pencegahan kesalahan, (6) website mudah dikenali, (7) fleksibilitas dan efisiensi penggunaan website, (8) estetika dan desain minimalis, (9) solusi apabila terjadi error yang dilakukan pengguna, (10) dukungan dan dokumentasi.

\section{METODE PENELITIAN}

Penelitian ini merupakan penelitian kuantitatif dengan menggunakan metode survei. Menurut Creswell, dalam metode survei, peneliti mendeskripsikan secara kuantitatif (angka-angka) kecenderungan-kecenderungan atau opini-opini dari suatu populasi dengan meneliti sampel populasi tersebut [8]. Penelitian ini bertujuan untuk menguji usability website SIA Universitas Islam Kalimantan Muhammad Arsyad Al Banjari agar mendapatkan umpan balik (feedback) untuk perkembangan website SIA tersebut selanjutnya. Adapun alasan peneliti memilih metode survei dalam penelitian ini, antara lain: (1) nilai ekonomis, (2) kecepatan dalam penyajian data penelitian, (3) dapat mengidentifikasi sifat-sifat populasi berdasarkan kelompok kecil individu.
Populasi pada penelitian ini adalah mahasiswa yang sedang menempuh studi di Universitas Islam Kalimantan Muhammad Arsyad Al Banjari yang berlokasi di Kota Banjarmasin, Kalimantan Selatan. Proses pengambilan sampel pada pada penelitian ini adalah menggunakan proses pemilihan sampel secara acak atau random sampling. Perhitungan jumlah sampel pada penelitian ini berdasarkan tabel Krejcie dan Morgan [9]. Sugiyono menjelaskan perhitungan sampel Krejcie dan Morgan didasarkan atas kesalahan $5 \%$. Jadi sampel yang diperoleh mempunyai kepercayaan 95\% terhadap populasi. Oleh karena itu dapat disimpulkan bahwa jumlah sampel yang diperlukan pada penelitian ini adalah minimal 376 mahasiswa. Jumlah tersebut diambil karena jumlah populasi mahasiswa Universitas Islam Kalimantan Muhammad Arsyad Al Banjari adalah sebesar 17.522 mahasiswa [10].

\begin{tabular}{|c|c|c|c|c|c|}
\hline $\mathrm{N}$ & $s$ & N & $s$ & N & $s$ \\
\hline 10 & 10 & 220 & 140 & 1.200 & 291 \\
\hline 15 & 14 & 230 & 144 & 1.300 & 297 \\
\hline 20 & 19 & 240 & 148 & 1.400 & 302 \\
\hline 25 & 24 & 250 & 152 & 1.500 & 306 \\
\hline 30 & 26 & 260 & 155 & 1.600 & 310 \\
\hline 35 & 32 & 270 & 159 & 1.700 & 313 \\
\hline 40 & 36 & 280 & 162 & 1.800 & 317 \\
\hline 45 & 40 & 290 & 165 & 1.9000 & 320 \\
\hline 50 & 44 & 300 & 169 & 2000 & 322 \\
\hline 55 & 48 & 320 & 175 & 2200 & 327 \\
\hline 00 & 52 & 340 & 181 & 2400 & 331 \\
\hline 65 & 56 & 360 & 186 & 2600 & 335 \\
\hline 70 & 59 & 380 & 191 & 2800 & 338 \\
\hline 75 & 63 & 400 & 196 & 3000 & 341 \\
\hline 20 & 66 & 420 & 201 & 3.500 & 346 \\
\hline$B 5$ & 70 & 440 & 205 & 4.000 & 351 \\
\hline 90 & 73 & 460 & 210 & 4.500 & 354 \\
\hline 95 & 76 & 460 & 214 & 5000 & 357 \\
\hline 100 & 80 & 500 & 217 & 6.000 & 361 \\
\hline 110 & 86 & 550 & 226 & 7.000 & 364 \\
\hline 120 & 92 & 600 & 234 & 8000 & 367 \\
\hline 130 & 97 & 850 & 242 & 9000 & 368 \\
\hline 140 & 103 & 700 & 246 & 10.000 & 370 \\
\hline 150 & 100 & 750 & 254 & 15000 & 375 \\
\hline 160 & 113 & 800 & 260 & 20.000 & 377 \\
\hline 170 & 118 & 850 & 265 & 30.000 & 379 \\
\hline 100 & 123 & 900 & 269 & 40.000 & 390 \\
\hline 190 & 127 & 950 & 274 & 50.000 & 381 \\
\hline 200 & 132 & 1.000 & 278 & 75.000 & 382 \\
\hline 210 & 136 & 1.100 & 285 & 100000 & 394 \\
\hline
\end{tabular}

\section{Tabel 1. Tabel Krejcie dan Morgan}

Peneliti menggunakan tiga instrumen untuk mendapatkan hasil yang lebih akurat. Instrumen penelitian tersebut adalah (1) kuesioner, (2) observasi, dan (3) wawancara. Kuesioner menggunakan skala likert. Skala likert adalah skala yang digunakan untuk mengukur sikap seseorang tentang suatu subjek sikap. Indikator-indikator dari variabel sikap terhadap suatu subjek merupakan titik tolak dalam membuat pertanyaan atau pernyataan yang harus diisi responden. Setiap 
pernyataan dihubungkan dengan jawaban yang berupa dukungan atau pernyataan sikap yang diungkapkan dengan jawaban yang berupa dukungan atau pernyataan sikap yang diungkapkan dengan kata-kata: sangat setuju (SS), setuju (S), netral (N), tidak setuju (TS), dan sangat tidak setuju (STS).

Dalam kuesioner yang dibagikan kepada para responden terdapat dua pernyataan yaitu pernyataan positif dan pernyataan negatif. Masing-masing mempunyai alternatif jawaban sangat setuju, setuju, netral, tidak setuju, dan sangat tidak setuju. Bentuk pernyataan positif diberi skor 5, 4, 3, 2, dan 1; sedangkan bentuk pernyataan negatif diberi skor 1, 2, 3, 4, dan 5 .

\begin{tabular}{|c|l|l|}
\hline $\begin{array}{c}\text { Alternatif } \\
\text { Jawaban }\end{array}$ & $\begin{array}{c}\text { Bobot } \\
\text { Pernyataan } \\
\text { Positif }\end{array}$ & $\begin{array}{c}\text { Bobot } \\
\text { Pernyataan } \\
\text { Negatif }\end{array}$ \\
\hline Sangat Setuju & 5 & 1 \\
\hline Setuju & 4 & 2 \\
\hline Ragu-ragu & 3 & 3 \\
\hline Tidak Setuju & 2 & 4 \\
\hline $\begin{array}{c}\text { Sangat Tidak } \\
\text { Setuju }\end{array}$ & 1 & 5 \\
\hline
\end{tabular}

Tabel 2. Bobot Nilai Pernyataan Positif dan Negatif Skala Likert

Pada observasi, peneliti melakukan pengamatan terhadap pengguna (mahasiswa) saat mengakses website SIA Universitas Islam Kalimantan Muhammad Arsyad Al Banjari. Peneliti kemudian akan mencatat pola-pola akses setiap pengguna dan menganalisisnya. Agar mengetahui permasalahan lebih mendalam peneliti juga melakukan wawancara. Wawancara dilakukan setelah observasi. Pertanyaan yang ditanyakan kepada mahasiswa yaitu sama dengan pernyataan kuesioner, akan tetapi peneliti lebih menggali lebih dalam alasan mahasiswa memilih pernyataan tersebut.

Penelitian ini dilakukan pada bulan November 2018 - Maret 2019 di Universitas Islam Kalimantan Muhammad Arsyad Al Banjari. Sedangkan untuk pelaksanaan dan tata cara pengumpulan data adalah sebagai berikut: (1) mahasiswa akan dipilih secara acak pada periode waktu yang telah ditetapkan dan diminta untuk mengisi kuesioner secara online, (2) perwakilan mahasiswa setiap fakultas dikumpulkan pada satu ruangan dan diminta satu per satu untuk maju ke depan untuk menjalankan tugas yang diberi oleh peneliti, peneliti kemudian mengobservasi dan mencatat pola-pola dari responden saat mengakses website SIA Universitas Islam Kalimantan Muhammad Arsyad Al Banjari, (3) tahap terakhir yaitu peneliti mewawancarai mahasiswa terkait kendala-kendala yang dihadapi ketika mengakses website tersebut.

\section{HASIL DAN PEMBAHASAN}

Penelitian ini menggunakan kuesioner yang diadaptasi dari Usability Heuristic Evaluation (UHE) yang bertujuan untuk mendapatkan informasi dari seberapa besar tingkat usability sebuah website. Dari adaptasi tersebut tersusun 15 pernyataan yang mewakili aspek-aspek pada UHE. Kuesioner dibagikan selama bulan Januari - Februari 2019 melalui internet dengan menggunakan Google Form. Total jumlah mahasiswa yang mengisi kuesioner ini adalah 414 mahasiswa yang berasal dari 7 Fakultas yaitu:

1. 196 mahasiswa dari Fakultas Teknologi Informasi $(47,3 \%)$

2. 98 mahasiswa dari Fakultas Kesehatan Masyarakat $(23,7 \%)$

3. 64 mahasiswa dari Fakultas Ekonomi $(15,5 \%)$

4. 40 mahasiswa dari Fakultas Keguruan dan Ilmu Pendidikan $(9,7 \%)$

5. 8 mahasiswa dari Fakultas Studi Islam $(1,9 \%)$

6. 4 mahasiswa dari Fakultas Hukum (1\%)

7. 4 mahasiswa dari Fakultas Teknik (1\%)

Sedangkan sebaran angkatan yang mengisi kuesioner yaitu :

1. 152 mahasiswa angkatan $2016(36,7 \%)$

2. 138 mahasiswa angkatan $2017(33,3 \%)$

3. 84 mahasiswa angkatan $2018(20,3 \%)$

4. 28 mahasiswa angkatan $2015(6,8 \%)$

5. 12 mahasiswa angkatan $2014(2,9 \%)$

Berikut adalah paparan data dari survei yang dilakukan melalui kuesioner: 


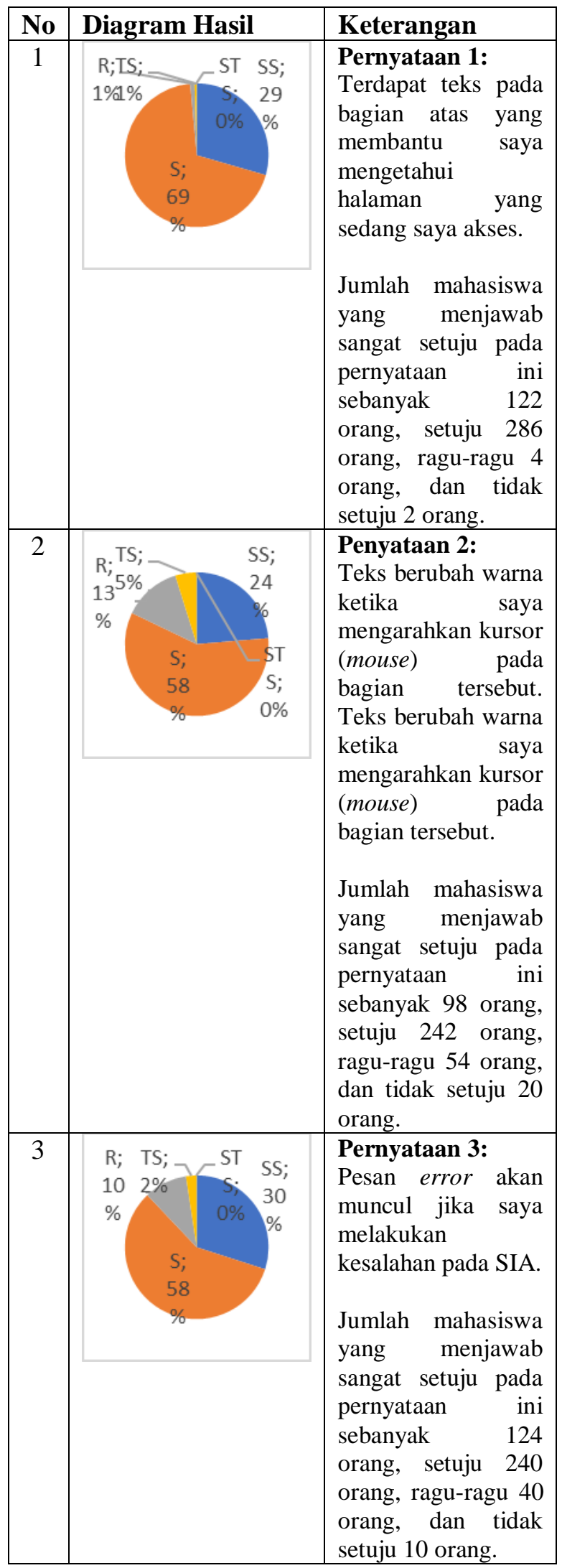

\begin{tabular}{|c|c|c|}
\hline 4 & $\begin{array}{l}\mathrm{R} ; \mathrm{TS} ; \\
3 \% 1 \%\end{array}$ & $\begin{array}{l}\text { Pernyataan 4: } \\
\text { SIA menggunakan } \\
\text { bahasa yang mudah } \\
\text { saya pahami. } \\
\text { Jumlah mahasiswa } \\
\text { yang menjawab } \\
\text { sangat setuju pada } \\
\text { pernyataan ini } \\
\text { sebanyak } 190 \\
\text { orang, setuju } 208 \\
\text { orang, ragu-ragu } 12 \\
\text { orang, dan tidak } \\
\text { setuju 4 orang. }\end{array}$ \\
\hline 5 & $\begin{array}{l}\text { R;TS; } \\
7 \% 1 \%\end{array}$ & $\begin{array}{l}\text { Pernyataan 5: } \\
\text { Saya dapat dengan } \\
\text { mudah memilih } \\
\text { halaman yang ingin } \\
\text { saya akses. } \\
\text { Jumlah mahasiswa } \\
\text { yang menjawab } \\
\text { sangat setuju pada } \\
\text { pernyataan ini } \\
\text { sebanyak } 140 \\
\text { orang, setuju } 236 \\
\text { orang, ragu-ragu } 30 \\
\text { orang, tidak setuju } 6 \\
\text { orang, dan sangat } \\
\text { tidak setuju } 2 \text { orang. }\end{array}$ \\
\hline 6 & $\begin{array}{l}\text { R;TS } \\
8 \% 1 \%\end{array}$ & $\begin{array}{l}\text { Pernyataan 6: } \\
\text { Saya dapat } \\
\text { membaca dengan } \\
\text { jelas teks yang } \\
\text { terdapat pada SIA. } \\
\text { Jumlah mahasiswa } \\
\text { yang menjawab } \\
\text { sangat setuju pada } \\
\text { pernyataan ini } \\
\text { sebanyak } \\
\text { orang, setuju } 226 \\
\text { orang, ragu-ragu } 32 \\
\text { orang, dan tidak } \\
\text { setuju 6 orang. }\end{array}$ \\
\hline 7 & $\begin{array}{ll}\mathrm{R} ; & \mathrm{TS} ; \\
12 & 3 \% \\
\% & \end{array}$ & $\begin{array}{l}\text { Pernyataan 7: } \\
\text { Terdapat panduan } \\
\text { yang membantu } \\
\text { saya untuk } \\
\text { menyelesaikan apa } \\
\text { yang ingin saya } \\
\text { lakukan di halaman } \\
\text { tersebut. } \\
\text { Jumlah mahasiswa } \\
\text { yang menjawab } \\
\text { sangat setuju pada } \\
\text { pernyataan ini }\end{array}$ \\
\hline
\end{tabular}




\begin{tabular}{|c|c|c|}
\hline & & $\begin{array}{ll}\text { sebanyak } & 112 \\
\text { orang, setuju } 242 \\
\text { orang, ragu-ragu } 48 \\
\text { orang, dan tidak } \\
\text { setuju 12 orang. }\end{array}$ \\
\hline 8 & $\begin{array}{r}\mathrm{R} ; \mathrm{TS} ; \\
6 \% 1 \%\end{array} \quad \begin{array}{r}\mathrm{ST} \\
\mathrm{S} ; \\
\end{array}$ & $\begin{array}{l}\text { Pernyataan 8: } \\
\text { Teks akan bewarna } \\
\text { merah ketika saya } \\
\text { salah isi. } \\
\text { Jumlah mahasiswa } \\
\text { yang menjawab } \\
\text { sangat setuju pada } \\
\text { pernyataan ini } \\
\text { sebanyak } \quad 142 \\
\text { orang, setuju } 240 \\
\text { orang, ragu-ragu } 26 \\
\text { orang, tidak setuju } 4 \\
\text { orang, dan sangat } \\
\text { tidak setuju } 2 \text { orang. }\end{array}$ \\
\hline 9 & $\begin{array}{cccc}\mathrm{R} ; & \mathrm{TS} ; & \mathrm{ST} & \mathrm{SS} ; \\
18 & 2 \% & \mathrm{~S} ; & 23 \\
\% & & 1 \% & \%\end{array}$ & 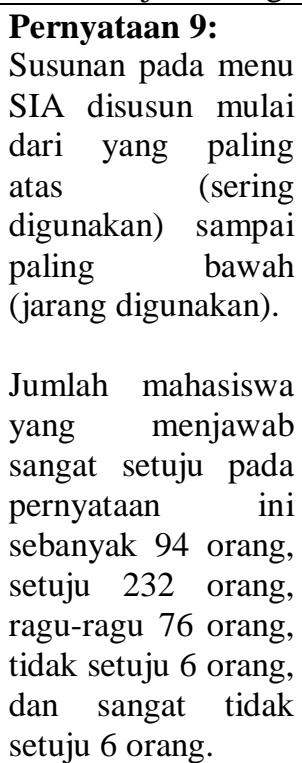 \\
\hline 10 & $\begin{array}{cccc}\text { TS; } & \text { ST } & 7 \\
16 & \text { S; } & \\
\% & 2 \% & \\
& & \\
\text { R; } & & \text { S; } \\
20 & & 45 \\
\% & & \%\end{array}$ & 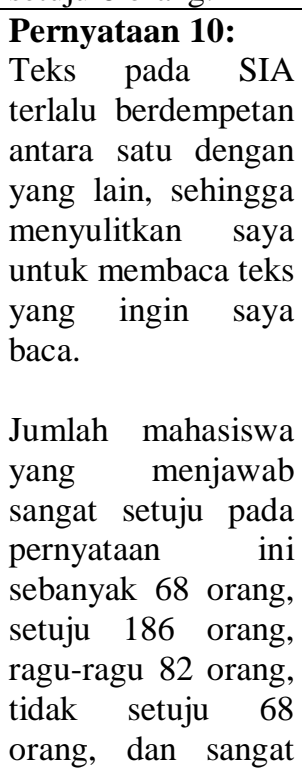 \\
\hline
\end{tabular}

\begin{tabular}{|c|c|c|}
\hline & & $\begin{array}{lll}\text { tidak } & \text { setuju } & 10 \\
\text { orang. } & & \\
\end{array}$ \\
\hline 11 & $\begin{array}{lll}\mathrm{R} ; & \mathrm{TS} ; & \mathrm{ST} \\
14 & 3 \% & \mathrm{SS} ; \\
\% & & \text { SS } \\
1 \% & \end{array}$ & \begin{tabular}{lr}
\multicolumn{3}{l}{ Pernyataan 11: } \\
Fasilitas pencarian \\
(search) pada & SIA \\
memudahkan saya \\
mencari mata kuliah \\
yang ingin saya \\
ambil. \\
Jumlah mahasiswa \\
yang menjawab \\
sangat setuju pada \\
pernyataan r ini \\
sebanyak $\quad 112$ \\
orang, setuju 226 \\
orang, ragu-ragu 60 \\
orang, tidak setuju \\
12 orang, dan \\
sangat tidak setuju 4 \\
orang.
\end{tabular} \\
\hline 12 & $\begin{array}{l}\mathrm{R} ; \mathrm{T} \\
9 \%\end{array}$ & 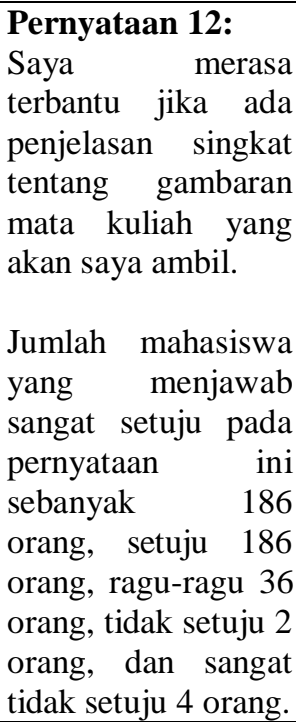 \\
\hline 13 & $\begin{array}{ccc}\text { TS; } & & \text { ST } \\
12 & & \text { S; } \\
\% & & 1 \% \\
& & \\
\mathrm{R} ; & \mathrm{S} ; & \mathrm{SS} ; \\
13 & 42 & 32 \\
\% & \% & \%\end{array}$ & 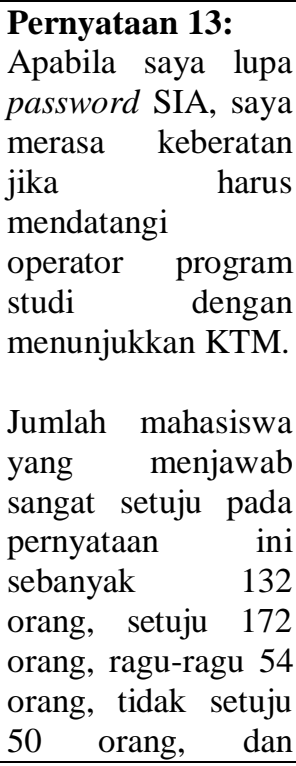 \\
\hline
\end{tabular}




\begin{tabular}{|c|c|c|}
\hline & & $\begin{array}{l}\text { sangat tidak setuju } 3 \\
\text { orang. }\end{array}$ \\
\hline 14 & $\begin{array}{r}\mathrm{ST} \\
\mathrm{R}_{3 \%}^{\mathrm{S} ;}\end{array}$ & $\begin{array}{l}\text { Pernyataan 14: } \\
\text { Saya puas dengan } \\
\text { tampilan SIA di } \\
\text { laptop. } \\
\text { Jumlah mahasiswa } \\
\text { yang menjawab } \\
\text { sangat setuju pada } \\
\text { pernyataan } r \text { ini } \\
\text { sebanyak } 258 \\
\text { orang, setuju } 172 \\
\text { orang, ragu-ragu } 44 \\
\text { orang, tidak setuju } \\
\text { 20 orang, dan } \\
\text { sangat tidak setuju } 8 \\
\text { orang. }\end{array}$ \\
\hline 15 & \begin{tabular}{c|} 
TS; \\
11 \\
$\%$ \\
\end{tabular} & 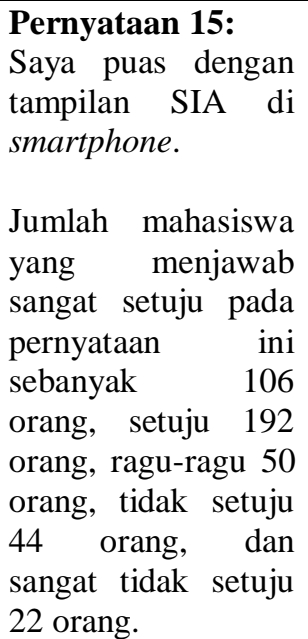 \\
\hline
\end{tabular}

Tabel 3. Paparan data kuesioner

Tahap selanjutnya adalah observasi. Observasi diperlukan untuk mengamati secara langsung kegiatan yang dilakukan mahasiswa saat mengakses SIA pada tanggal $16-28$ Februari 2019. Terdapat 8 mahasiswa yang dipilih secara acak untuk mewakili setiap fakultas. Peneliti memberikan beberapa tugas untuk dilakukan oleh mahasiswa kemudian direkam dan diamati. Peneliti menyediakan 2 alat untuk mengakses SIA yaitu laptop dengan layar 15,6 inch dan smartphone dengan layar 4,7 inci. Adapun tugas yang diberikan yaitu :

1. Log-in menggunakan username dan password.

2. Mengubah informasi pribadi, mengganti foto, dan mengubah password pada bagian akun.

3. Mengecek jadwal ketersediaan mata kuliah dan kelas pada bagian akademika.
4. Mengisi kartu rencana studi (KRS) pada bagian akademika.

5. Log-out.

Agar mengetahui permasalahan lebih mendalam peneliti juga melakukan wawancara. Wawancara dilakukan setelah observasi. Pertanyaan yang ditanyakan kepada mahasiswa yaitu sama dengan pernyataan kuesioner, akan tetapi peneliti lebih menggali lebih dalam alasan mahasiswa memilih pernyataan tersebut. Dari semua hasil wawancara, peneliti kemudian mencatat permasalahan yang dihadapi oleh mahasiswa ketika mengakses SIA yaitu :

1. Kurang responsif ketika mengklik salah satu menu, harus beberapa kali mengklik untuk mengakses menu tersebut.

2. Tulisan terlalu kecil sehingga diperlukan zoom-in.

3. Tampilan ketinggalan jaman.

4. Tampilan kurang bagus ketika diakses melalui smartphone.

5. Fitur dan tampilan tidak pernah diperbaharui secara berkesinambungan.

6. Tidak bisa mengubah form pada bagian profil dan bagian lupa password.

7. Informasi tidak sesuai dengan yang tertera pada SIA (informasi tentang mata kuliah \& nilai).

Setelah memaparkan data yang didapat dari kuesioner, observasi, dan wawancara, tahap selanjutnya yaitu adalah menganalisis data. Peneliti kemudian mengkategorikan 15 pernyataan tersebut menjadi 5 kategori yaitu:

1. Navigasi (pernyataan nomor $1,3,5,9$ dan 11)

2. Tipografi/teks (pernyataan nomor 4,6 , dan 10)

3. Warna (pernyataan 2 dan 8 )

4. Pencegahan Kesalahan Pengguna (pernyataan nomor 7,12 , dan 13)

5. Kepuasan Pengguna (pernyataan nomor 14 dan 15)

Pada bagian navigasi didapat hasil bahwa pengguna mengetahui dan mudah memilih halaman yang sedang ataupun ingin ia akses. Pengguna juga mengetahui apabila ia melakukan kesalahan input data dengan 
adanya pesan error yang muncul. Pengguna juga merasa puas dengan susunan menu yang terletak pada bagian atas dan bagian kiri SIA. Akan tetapi pengguna merasa kesulitan dalam mencari mata kuliah yang hendak ia ambil karena tidak ada fasilitas pencarian (search).

Pada bagian tipografi/teks didapat hasil bahwa pengguna tidak mengalami kesulitan dalam memahami bahasa yang ada pada SIA. Pengguna juga dapat dengan jelas membaca teks karena adanya teks yang besar dan jelas di setiap halaman. Namun pengguna merasa kesulitan membaca teks yang terlalu berdempetan antara satu dengan yang lain, khususnya pada smartphone yang mengharuskan pengguna untuk melakukan zoom-in dan zoom-out pada setiap halaman.

Pada bagian warna didapat hasil bahwa pengguna puas dengan perubahan warna apabila kursor (mouse) diarahkan pada bagian tertentu, sehingga pengguna mengetahui bagian menu mana yang ingin ia tuju. Pengguna juga setuju bahwa perubahan warna yang terjadi apabila salah isi atau lupa mengisi form yang ada pada SIA.

Pada bagian pencegahan kesalahan pengguna didapat hasil bahwa pengguna merasa terbantu dengan adanya panduan untuk menyelesaikan apa yang ingin dilakukan pada halaman tersebut. Akan tetapi pengguna mengalami kesulitan dalam memilih mata kuliah karena tidak adanya penjelasan singkat tentang gambaran mata kuliah yang akan diambil. Pengguna juga merasa keberatan dan berharap dapat menyelesaikan kesalahan yang dilakukan pada SIA secara online tanpa harus mendatangi operator SIA, contohnya seperti menunjukkan KTM apabila lupa password, dll.

Pada bagian kepuasan pengguna didapat hasil bahwa pengguna yang mengisi kuesioner puas dengan tampilan SIA pada laptop dan smartphone. Namun terdapat perbedaan jawaban pada saat wawancara, 6 dari 8 mahasiswa menjelaskan mereka tidak puas dari segi tampilan. Jika dikaitkan dengan bagian tipografi/teks, terdapat kesamaan kendala yang dihadapi oleh pengguna yang mengakses via smartphone yaitu pengguna harus melakukan zoom-in dan zoom-out pada setiap halaman.

\section{KESIMPULAN}

Penulis menyimpulkan beberapa hal yang dianggap penting dari hasil analisis dengan mengaitkan ketiga hasil data yang diambil sebelumnya. Secara keseluruhan mahasiswa sebagai pengguna merasa puas dengan fungsi SIA, namun tidak puas dari segi tampilan. Tampilan SIA yang dianggap monoton dan tidak menyesuaikan dengan tampilan mobile atau mengikuti ukuran layar smartphone yang digunakan untuk mengakses menjadi salah satu faktor ketidakpuasan tersebut. Pengguna mengharapkan adanya perbaharuan tampilan SIA secara berkala. Bagian manajemen data akademik yang meliputi menu-menu seperti pengisian KRS mahasiswa, informasi KRS dan KHS, transkrip akademik, informasi jadwal kuliah dan ujian, dll. yang mengakomodasi kebutuhan mahasiswa memang merupakan fungsi utama SIA, namun akan menjadi tidak seimbang apabila website SIA tidak memperhatikan tampilannya. Tampilan website menjadi salah satu faktor yang penting agar fungsi usability website SIA tercapai dengan baik.

Berikut adalah beberapa saran yang dapat menjadi bahan pertimbangan untuk peneliti selanjutnya yang meneliti topik terkait dengan website SIA yaitu :

1. Jumlah sampel dalam penelitian ini sudah mencukupi, namun sebaran sampel belum merata disetiap fakultas maupun angkatan. Walaupun hal tersebut tidak berpengaruh signifikan kepada hasil, akan tetapi lebih baik jika sebaran sampel lebih merata.

2. Perbedaan ukuran layar laptop dan ukuran layar smartphone yang sering dipakai mahasiswa untuk mengakses SIA dengan yang digunakan dalam observasi menyebabkan mahasiswa kurang menguasai karena tidak terbiasa menggunakannya.

3. Terbatasnya pengetahuan mahasiswa mengenai istilah-istilah yang digunakan pada saat wawancara menyebabkan perbedaan interpretasi antara peneliti dengan mahasiswa yang diwawancarai.

4. Pernyataan kuesioner pada penelitian ini merupakan adaptasi dari Usability Heuristic Evaluation (UHE). Penelitian selanjutnya 
dapat menerapkan focus group discussion (FGD) dengan stake holder terkait dalam merancang kuesioner agar data yang didapatkan lebih akurat.

\section{REFERENSI}

[1] Indrajit, R. E. (2000). Manajemen Sistem informasi dan Teknologi informasi. Jakarta: PT Elex Media Komputindo.

[2] Beaird, J. (2010). The Principles of Beautiful Web Design. Canada: Site Point.

[3] Sidik, A., Ahmad, H. A., \& Sriwarno, A. B. (2017). Studi Faktor Usability pada Desain Layout Website Berita Mobile Indonesia. Semnasteknomedia Online, 5(1), 4-5.

[4] Rais, N. A. R., Agustiyo, H., \& Ardiansyah, M. A. (2018). Evaluasi Heuristic Study Kasus Tiket.com. Semnasteknomedia Online, 6(1), 1-8.

[5] Sutabri, T. (2012). Sistem Informasi Manajemen. Yogyakarta: Andi Publisher.

[6] Nielsen, J. (1994). Usability Engineering. Elsevier.

[7] Nielsen, J. (2012). Usability 101: Introduction to Usability.

[8] Creswell, J. W. (2009). Research Design: Pendekatan Kualitatif, Kuantitatif, dan Mixed. Yogyakarta: Pustaka Pelajar.

[9] Sugiyono. (2009). Metode Penelitian Kuantitatif, Kualitatif dan R\&D.

Bandung: Alfabeta.

[10] Forlapdikti., https://forlap.ristekdikti.go.id. Diakses bulan November 2018. 